\title{
Academic Tenure and "White Male" Standards: Some Lessons from the Patent Law
}

\author{
Stephen L. Cartert
}

At a conference not long ago, I met a professor from another law school who writes, as I sometimes do, about the efforts of the legal system to mediate the conflicts that arise between religion and society. Like me, she is a critic of the way the law currently deals with these conflicts, fearing, as I do, that the legal culture tends to trivialize and denigrate religious devotion. So one might have thought we would have a lot in common. So did I, and I anticipated a fruitful discussion of our shared scholarly interest - until the conversation took a disturbing turn.

My new acquaintance told me that she was familiar with two of my articles touching on religion and society. But only one of them, she told me, was clearly written by someone who is black. Had she known that I was black, she said, she would have gotten so much more out of the other one. ${ }^{1}$ Puzzled, I asked why this should be so. She seemed surprised at the question. It would, she said, have placed the argument in its proper perspective. This answer, however, only increased my bewilderment. Why, I asked, could she not simply take the argument as it was, evaluating it without regard to the color of my skin? Because, she explained patiently, she needed a context in which to evaluate the argument. Only then, she added gently, might we have a real conversation. $^{2}$

I found this saddening, and I told her so. In the guise of bringing us together, I suggested, her philosophy (and not only hers!) was actually pushing us apart. The reason, I said, is that she was saying, in effect, "Tell me about yourself, and then we can have a real conversation." My vision of scholarship, and indeed of life, works the other way around, shedding preconceptions in favor of something like: "Let's have a conversation, and that is how I will learn about you." Certainly the professor was right that knowledge of my skin color

† William Nelson Cromwell Professor of Law, Yale University. As always, I am grateful to Enola Aird.

1. The import of my new friend's claim, although I did not pursue it, was that she assumed that the author of the article in question was white, which, in scholarship as in all professions, is the default value for individuals whose colors are unknown.

2. The article that was, according to my new friend, clearly written by someone black was Carter, Loving the Messenger, 1 YALE J.L. \& HUM. 317 (1989), an essay on the conversion of black activist Julius Lester to Judaism. The article that did not reveal its author's color was Carter, Evolutionism, Creationism, and Treating Religion as a Hobby, 1987 DUKE L.J. 977. 
would have placed the article in a context, but what context would it have been? Had she known that I was black, she might have attached all sorts of significance to what we might call the colorless article, but the significance would have been born of her conception of the meaning of blackness, not necessarily mine; the possibility that she missed is that the article included everything that I thought important for understanding the $I$ who was writing. She wanted me as the author to tell her the things that she considered important about the you who was writing. (I noticed, for example, that although both of the articles in question were at least in part about religion, she did not seem bothered that I did not identify my religious faith, if any, in either one.) My answer is that the you is discovered in the process of reading, but my new friend, perhaps unsurprisingly in this deconstructionist era, had her very profound doubts.

The odd thing is that the one claim that seemed absolutely inadmissible is that the argument in either article might stand on its own. Evidently, there is no "on its own" any longer. Not only must one know the context, one must know the author. The more one knows about the author, the less work one has to do to evaluate the argument. And much of the time, it seems, one of the most important facts to know about the author is the author's race, by which, in America, we mean skin color.

I am troubled by the increasing number of academics who seem very serious about the idea that knowledge of the author's race helps create a better context for understanding the author's argument, not just on subjects relating to race, but on other subjects as well; the article that my new friend thought needed a context was, after all, about religion, not race. Last year I prepared a rather lengthy analysis of the role of the International Trade Commission in policing claims of software piracy. ${ }^{3}$ Should I have stated my race on the face of the article? My race and perhaps other aspects of my history-to give it a "context"? (A sympathetic bond with the oppressed people of the Third World perhaps?) Might the careful reader glean these without my assistance? Or did I hide my true and best voice, the voice of color, under a patina of whiteness?

As I read Alex Johnson's rich but perplexing article, ${ }^{4}$ the answer might well be the last. Johnson's article, styled as a reaction to one essay of mine on some of the difficulties of affirmative action ${ }^{5}$ and a longer piece by Randall Kennedy on evaluation of scholarship, ${ }^{6}$ is an effort to find a measure of common ground in the debate over the interaction between the experience of racial

3. Carter, Gaining Without Venturing: The New Section 337 and the New Software Protections, in TECHNOLOGY, TRADE \& WORLD COMPETTIION: PROTECTING INTELlECTUAL PROPERTY WITH TRADE SANCTIONS 93-134 (1990).

4. Johnson, The New Voice of Color, 100 YALE L.J. 2007 (1991).

5. Carter, The Best Black, and Other Tales, 1 ReCONSTRUCTION No. 1, 1990, at 6. A modified version of this essay appears as chapter 3 in S. CARTER, REFLECTIONS OF AN AFFIRMATIVE ACTION BABY (forthcoming 1991).

6. Kennedy, Racial Critiques of Legal Academia, 102 HARV. L. REV. 1745 (1989). 
discrimination in the United States and the actual work of legal scholars. The argument is of considerable importance, not only because it ultimately bears on questions of faculty hiring and tenure, but because it addresses what Kenneth Clark has described as a fundamental question in a civilized society: how to measure excellence. ${ }^{7}$

To the extent that Johnson's argument is that every writer is influenced by his or her background, what he says is of course indisputable. It is when Johnson moves beyond that proposition to begin to talk about "majoritarian" and "white male" standards that my perplexity begins-perplexity not only about what he supposes the standards for evaluating scholarly excellence should be, but also about his message for scholars like myself, who, according to Johnson, choose different scholarly voices for different scholarly occasions.

The process of categorization, whatever its benefits in analytic efficiency, has become one of the great tragedies of our age. If the proper label can be found for another person's views or work, there is scarcely any need for argument; certainly there is little need to engage with what another person has actually written. I believe in dialogue; I believe in people talking to each other rather than around each other or to caricatures of each other. Too often in our unhappy world, people whose disagreements run deep decide that the time to talk has passed-even when conversation as a means to resolve their differences has not even been tried. It was my commitment to open and serious dialogue, I think, that more than anything else moved me to enter the academic world. Perhaps I was naive, but I genuinely wanted to work among people whose joy was talking about ideas.

Nowadays, however, a great deal of academic dialogue turns out to be not about the ideas that people express but about the people who express the ideas. It isn't what one says that matters, it is who is doing the saying. This is the problem I had with the professor who said she would have gotten more out of one of my articles had I told the reader I was black; she might have seen the label as an aid to understanding, but my suspicion is that such "context" actually makes it easier for the reader to disengage from the writer. The more assumptions one can attach to the author before the process of reading begins, the greater the number of biases and preconceptions that one will bring to the reading itself. And the greater the number of biases and preconceptions the reader brings along, the lower the probability that true communication might occur.

Alex Johnson's article is very much in this tradition of scholarship about scholars. Just consider the jargon scattered through it: Majoritarian. Voice of Color. Neutrality. Hierarchical. Exclusion. Difference. White Male. Objectivity. String enough of these code words together and they almost make an argument in themselves; except that the kind of argument they make is one not about the

7. See K. CLARK, The Duty of the Intellectual, in PATHOS OF POWER 19-20 (1974). 
relative merits of different scholarly ideas but about the various convenient boxes into which different scholars might be stuffed. And one of the scholars Johnson seems in a hurry to box is me.

According to Johnson, I am an elitist who has accepted what he calls the "Hierarchical Majoritarian" standard for evaluating legal scholarship. Sometimes, it seems, I have written in the voice of color (or, as Johnson says, one of the many voices of color). According to Johnson, my recent essay on affirmative action, The Best Black, and Other Tales, was written in the voice of color, even though others, writing in the same voice, might offer analyses different from mine. ${ }^{8}$ I suppose that the professor I met who shared my interest in religion and society would say that the article on religion that clearly identified my race was written in the voice of color, too. At other times, however, I have evidently selected instead the voice of my "majoritarian" peers. Lest the point be obscured by jargon, what Johnson is saying is that I sometimes write like a white male instead of a black one.

Although Johnson is careful to insist that he sees nothing wrong and much right with scholars who are people of color writing other than in the voice of color, ${ }^{9}$ there is about his article a flavor of critique, a sense that the voice of color is specially to be valued in a way that the majoritarian voice is not. I suppose that I am old-fashioned to think so, but to suggest that the judgment on the quality of a work of scholarship should turn in any way on the identity of the scholar (I do not deny that sometimes it does) seems to violate what John Hope Franklin, one of the preeminent historians of the twentieth century, has called "a basic principle of scholarship—namely, that given the materials and techniques of scholarship and given the mental capacity, any person could engage in the study of any particular field." 10

In this brief essay, I do not plan to join the debate over the existence and worth of a voice of color. (Johnson says that I have expressed doubts on both, but that is not an accurate reading of my work.) Nor is it my intention to engage in point-by-point rebuttal or even rejoinder. Instead, after a few paragraphs to clarify some aspects of my views that I think Johnson has inadvertently misstated, followed by a short comment on the notion that an author's sympathies or affiliations are more important than the author's arguments, I will spend the rest of this essay setting out in more detail what I only sketched in the Best Black essay: what I consider the proper standard for academic tenure in law schools-a standard, in my view, that does not turn on the perspective from which an article is written or the subject that a scholar chooses to tackle. The standard I propose, which is inspired in part by my years of teaching patent

8. Johnson, supra note 4, at 2016, 2035-37.

9. See id. at 2036-37. He makes the same point in more detail in a recent article. Johnson, Racial Critiques of Legal Academia: A Reply in Favor of Context, 43 STAN. L. REV. 137, 159-61 (1990).

10. J. FRANKLIN, The Dilemma of the American Negro Scholar, in RACE AND HISTORY: SELECTED ESSAYS 1938-1988, at 295, 301 (1989). 
law, would require of all scholarship that it fulfill the essential purpose of adding to human knowledge, a deceptively simple test that would, I believe, open new vistas for all scholars working to attain it.

\section{II}

Johnson says lots of things about what I have written, some of them kind, some of them less so, and while I am not the sort to engage in a lengthy defense of my own work (after all, readers who find the debate interesting can actually look at the original source) it is useful to sort through some of his more important assertions about my Best Black essay and my other scholarship, because the presumed accuracy of what he says about my work is, in some cases, an element of Johnson's argument. I am loath to summarize in a few paragraphs what $I$ have elsewhere set forth at length, but in this case, $I$ think, before proceeding to discuss what Johnson says about my work, it is useful to take a moment and try to make both parts of my argument clear, since I fear that Johnson's article, perhaps understandably, does not.

My principal claim in the Best Black essay-a claim that I do not take Johnson to dispute-is that white people $d o$ judge black people by different standards, and that even in academia, well meaning white people do advocate the hiring of people of color whom they do not think would be good enough if not for skin color." This is what I mean by what I call the "best black syndrome": the tendency of many white people to establish two categories for excellence, one for the people who are the best and another for the black people who are the best. Underlying the best black syndrome, I contend, is an assumption that black people cannot compete intellectually with white people, an assumption I find offensive and one I emphatically reject. Most of the argumentation and all of the examples in the essay are devoted to setting out the costs of the syndrome, as well as explaining how it is often reinforced by the rhetorical style of some (but not all) arguments in favor of affirmative action.

My subsidiary claim - the one that Johnson takes as his text-is that it is possible to develop a standard for judging scholarship that does not turn on color or voice. This, I assume, is what leads to his charge that I have adopted what he calls the Hierarchical Majoritarian standard for judging scholarly quality. Why he imagines that I suppose the standard that I defend in the essay to be the standard that is already applied by institutions dominated by white professors I have no idea, for, in my discussion of what I call the "star system," I sharply criticize the favoritism and elitism that work to the disadvantage of teaching candidates who are not white and who may be just as good as white candidates who are hired because they have the right friends. ${ }^{12}$ As an approach

11. See Carter, The Best Black, and Other Tales, supra note 5, at 7-9.

12. Id. at 7-9, 26-29. 
to faculty hiring, or to advancement in any other profession, the star system is a racially exclusionary corruption of an otherwise defensible meritocratic ideal, and I am appalled that so many of my colleagues, at Yale and elsewhere, are untroubled at the notion of doing business this way.

Among my goals in the Best Black essay was to point the way toward a better standard for evaluating scholarship, a standard that would not disadvantage work of high quality, no matter what the author's perspective. ${ }^{13}$ I will shortly explain in more detail how my proposed standard would operate and why $I$ am confident that it would not disadvantage any serious scholarly perspective. But first I must offer some brief commentary about the ways in which a misreading of my work seems to have pushed part of Johnson's response to it off the track.

The initial point that must be made is that Johnson styles the parts of his article that concern my work as though he is critiquing my scholarship on race, but he chooses to offer his critique only through a commentary on my Best Black essay. In an important sense, this involves a trope, albeit a useful one for his purposes. The essay is not the same as my scholarship; it is, for example, devoid of footnotes. If his goal is to suggest to readers what my views are, it would have been useful for him to discuss the best evidence of them, the articles in which $I$ discuss the principal issues that he raises.

I offer a single example of a question about my views that could have been resolved by considering my other work. Johnson says that I "question] the existence and worth" of a distinctive voice of color, and (in something of a contradiction) that I "equivocate" over its worth and existence. ${ }^{14}$ In the essay that he critiques, what I say about the point is this: "The argument over difference in scholarly perspective is too complex to rehearse here."15 The implication is that $I$ have rehearsed it elsewhere, which, in fact, is true. Looking over my other work in the area, I am not sure how Johnson could possibly believe that I dispute, or even equivocate on, the proposition that black people and white people are not the same, or that these differences will sometimes carry over into the scholarly world as into any other. Not only have I never denied the proposition, I have actually endorsed it, albeit not in the narrative essay that Johnson has mysteriously chosen as the focus for his critique.

The interested reader might, for example, peruse my article entitled When Victims Happen To Be Black, published in The Yale Law Journal two years before the Best Black piece, in which I discuss the Goetz trial and capital sentencing by making use of the distinction that Johnson says I doubt. ${ }^{16}$ In

13. I realize that part of Johnson's quarrel is over the meaning, if there is one, of the word "quality," but I will come to that point presently.

14. Johnson, supra note 4 , at 2012.

15. Carter, The Best Black, and Other Tales, supra note 5 , at 31.

16. See Carter, When Victims Happen To Be Black, 97 YALE L.J. 420 (1988). Johnson does cite this piece elsewhere in his article. See Johnson, supra note 4, at 2036 n.121. 
my article on Loving the Messenger, published in The Yale Journal of Law and the Humanities one year before the Best Black piece, I explain that I do not so much doubt the proposition of difference as worry about the harm I think will very likely come of making too much of it. ${ }^{17}$ In that article, I also detail the argument that I do not "rehearse" in the Best Black piece, suggesting that the so-called voice of color takes many forms, some of them contradictory, spanning a spectrum from left to right. ${ }^{18}$ In a forthcoming book, Reflections of an Affirmative Action Baby, I further explain the reasons that I think the trend toward celebrating difference as a qualification or merit indicator is likely to prove a tragic mistake.

Johnson repeatedly suggests that I have accepted a majoritarian vision of some "objective" standard for evaluating scholarship. ${ }^{19}$ There is no such language in any of my relevant work, and, as I have said, I do not accept someone else's vision of the criteria for evaluating scholarship: I offer my own. I think, however, that Johnson and I may have a substantive disagreement on the meaning of the word "objective," which is what transforms his suggestion into the pejorative that he evidently means it to be. A principal focus of modern scholarship, and not only in law, has been to assault the idea that one can evaluate anything without significant reference to one's own values. Okay, point taken, although this does not answer the question of what one should try to do. The knowledge that perfectly unbiased observation is impossible should instill in all of us a healthy degree of caution in the certainty of our rightness but, eventually, one must move. There are reasons that scholars should strive for dispassion, not the least of which is the importance of retaining a distinction between is and ought. I am not sure how critique is possible if one lacks accurate information, the $i s$; and I am not sure how evaluation is possible if one lacks a standpoint from which to pursue the ought. The alternative is morally monstrous: suddenly no one is capable of judging anybody else. ${ }^{20}$ On this point, I agree with Ronald Dworkin in hoping that we can stop tossing around such words as "objectivity" as though they possess an agreed and substantively negative content. ${ }^{21}$

17. Carter, Loving the Messenger, supra note 2.

18. Id. at 320-34. I do not claim to have originated the idea that there are many voices of color rather than one. That I take to be a major point of Randall Kennedy's piece, Racial Critiques, supra note 6, as well as an argument pressed for decades by black intellectuals from W.E.B. DuBois to Zora Neale Hurston to James Baldwin to Henry Louis Gates. In his current article (and the previous Stanford Law Review article on which he relies, Johnson, supra note 9, at 155-56) Johnson ringingly endorses the same proposition although he for some reason seems to treat it as new.

19. See Johnson, supra note 4, 2016-17, 2035-37.

20. It is no answer to say that the victims of oppression will have the monopoly on judgment, because if one does not believe in the possibility of neutrality in the sense of making moral judgment in accordance with disciplining rules, there is no standpoint from which to determine who the victims are and who the oppressors are-a matter very much at issue, for example, in the Persian Gulf War and, indeed, in the Middle East generally.

21. See Dworkin, My Reply to Stanley Fish (and Walter Benn Michaels): Please Don't Talk About Objectivity Any More, in THE POLITICS OF INTERPRETATION 287, 297-303 (W.J.T. Mitchell ed. 1983). 
Johnson further asserts that I "to a lesser degree" believe that quality is shaped by professional consensus or that we do not know how much scholarship is worth until we see the reaction of white professors to it. ${ }^{22}$ Johnson never offers any citations to my work in support of his statement that I believe this. Since my view is that quality is intrinsic, I could hardly believe what he suggests. For example, I do not suppose for a moment that the value of Johnson's article turns on whether it is published in The Yale Law Journal or anywhere else. My judgment on its quality certainly does not turn on whether anybody else, black or white or any other color, likes it. Of course, if someone thinks less of it than I do, or thinks more of some other article than I do, I am happy to listen to argument, to engage on the issue, and even to have my mind changed, for I am a believer in dialogue. But I do not imagine that professional reception is by itself a mark of quality. What I do think one learns from professional reception-and this is the point I was trying to make in the Best Black piece-is what the profession thinks of the work.

I will plead guilty to caring about the professional reception of my work, in the sense that I care about my reputation as a scholar. I do not imagine that there are many scholars who do not care at all about their reputations, although there are doubtless some. But although the reactions to my work from people whose judgments I respect might shape my own opinion on the quality of my work, that is not the principal reason that professional reaction matters. Johnson misses, I think, the important distinction between the quality of a piece of writing and the reward for a piece of writing. The reaction of colleagues is obviously central to gaining reward, and the most useful way of pursuing a positive reaction (assuming that the star system is unavailable) is to convince one's colleagues of the quality of the work. But failure to convince one's colleagues does not mean that the work is of low quality; it only means that there will be no academic reward for it. Our task as participants in and observers of this system is to press for adoption of academic standards that will ensure a closer correspondence (there will never be an identity) between value and reward.

There is an irony here. The entire construct of Johnson's article is to deny the possibility of neutrality and objectivity, which in turn would seem to make it implausible to suggest that anything has intrinsic value. If this is so-and this is an example of what I mean by the confusion over the proper use of such words as "objective"-then no scholarly work is better than any

22. See Johnson, supra note 4, at 2016. Johnson also suggests that I "appear to be hostile to the conception of the voice of color because of its potentially stigmatizing effect on the interpretation of scholarship prepared by scholars of color." Id. at 2016. Although I am not sure just what Johnson means by this, I suspect that he is suggesting that I fear that a perceived academic hostility toward the notion of a voice of color will carry over into evaluations of my own work. If I read Johnson wrong, I am sorry; if I read him right, his argument is a bit ad hominem for my taste, and, in any event, does not reflect my view. No such suggestion appears in any of my work, which probably explains why he cites nothing in support of his contention. 
other scholarly work, response is finally everything, and all the argument is really about is whose response matters. This approach reduces the debate over the voice of color to an argument over who gets to hand out the goodies, with nothing, after all, to say about the quality of scholarship. If this is what he does think (and, again, I may be misreading him), it is small wonder that he treats the word "hierarchical" like an insult. But I hope that I read him wrong, for I shudder to imagine a university faculty devoted explicitly to denying the possibility of scholarly excellence.

In The Duty of the Intellectual, the thought-provoking essay that opens his very fine book Pathos of Power, the renowned psychologist Kenneth Clark makes the following observation:

An unfinished task of our society-probably one that must be clearly identified, defined, and justified by intellectuals-is to learn to differentiate between democratic philosophy, goals, and methods and stable standards of excellence. Literalistic egalitarianism, appropriate and relevant to problems of political and social life, cannot be permitted to invade and dominate the crucial areas of the intellect, aesthetics, and ethics. ${ }^{23}$

The point of the passage is perfectly straightforward and sensible: a commitment to inclusionary politics bears no necessary relation to a judgment about what is good and fine and right and what is bad and poor and wrong. To me, as a member of a university faculty, this proposition is sometimes a difficult one to bear in mind because of the remarkable force of the idea of leveling as a methodology for considering the quality of scholarship: in the academy in these days of doubt, there are people, many of them, who believe that the pursuit of excellence is impossible (or, as a professor at one of the nation's best universities has suggested, possible but immoral) and comparative judgments are a bad joke.

I do not want to see the discussion over the relationship between scholarship and experience transformed into a part of the same movement. At present, it plainly is not. The conversation is about how one judges scholarly excellence, not over whether scholarly excellence is possible. Should the perspective from which an article is written be weighed in the balance of quality or not? This, I think, is an important conversation, one that Randall Kennedy has entered into quite forcefully in the Harvard Law Review article ${ }^{24}$ that has earned him so many inappropriate brickbats. My answer to the question is no, for the reasons stated by Franklin, ${ }^{25}$ but, as I will explain presently, this functional judgment bears no relation to the aesthetic questions of value that seem to drive so much of Johnson's argument. My concern is that Johnson's approach might well leave

23. K. CLARK, supra note 7, at 20.

24. See Kennedy, supra note 6, at 1801-07.

25. See J. FRANKLIN, supra note 10, at 301 . 
the impression that the debate is over not how one judges quality but whether quality can be judged.

Finally, let me put the record straight on a more sensitive point. Johnson accuses me, at least implicitly, of believing that the work of scholars of color is not as good as the work of other scholars. ${ }^{26}$ Here, I think, he has caught me out, but I plead guilty only to inadequate phraseology. A principal argument in the Best Black essay was that people of color who would do just as well as people who are white are excluded through the "star system" to which I adverted above. ${ }^{27}$ At the same time, I argued that people who are hired even though they are not expected to be good scholars are less likely to do good scholarship than people hired because they are, if - a big if - the people doing the hiring have in place a good system for assessing scholarly promise. ${ }^{28}$ In a footnote I tried to make clear that I was speaking of judgments of quality made by others (in this case the hypothetical faculty), not about something intrinsic, and that my only strong claim was that the others were entitled to their opinions. ${ }^{29}$ But a footnote, apparently, is not enough caution when one proceeds, as I did in that piece, to spin a lengthy hypothetical that takes the footnote's assumption as its starting point. Evidently, it is possible to read my argument, as many people did, as suggesting that I harbor doubts about the abilities of scholars of color. ${ }^{30}$ That was not my intention, but the fact that I labored the hypothetical plainly made it easy for the reader to gain this impression. This was an unfortunate error in judgment, one that caused pain and anguish to many people, and I am sorry for it. ${ }^{31}$

There is a point here worth emphasizing, however. There is an important difference between the claim that the standards that law schools use in evaluating scholarship are corrupt and the claim that the standards that law schools use are racially exclusionary. In discussing the star system, I was concerned principally with one area in which I think that the standards are both. The claim that Johnson presses, however, is not that the standards are corrupt and exclusionary but that they are biased and exclusionary; ${ }^{32}$ in other words, that by applying their Hierarchical Majoritarian standard, law schools adopt a standard that can be applied in a rational manner (which the star system cannot) but that works to exclude scholarly perspectives that, according to Johnson, the academy should instead be embracing.

26. See Johnson, supra note 4, at 2013-14.

27. See Carter, The Best Black, and Other Tales, supra note 5, at 26-29.

28. Id. at 30 .

29. $I d$. at 30 n.2.

30. Among those who have read my Best Black essay this way is Girardeau Spann, a law professor at Georgetown, whose letter appears, along with my rejoinder, in Reconstruction. See Spann, Correspondence, 1 ReCONSTRUCTION No. 2, 1990, at 2-3, 5-6.

31. When a revised version of the essay is published in my book, the extended hypothetical will be omitted.

32. See Johnson, supra note 4, at 2014-15. 
I have not defended in the past, and will not defend now, the standards that law schools use to evaluate scholarship, although I must admit a degree of puzzlement over the notion that this amorphous group, white males, actually shares one or even a small subset of standards. After nearly a decade of sitting through faculty meetings and listening to my colleagues discussing scholarship, I am quite certain that there is no such animal as the "majoritarian perspective" on these matters, and, if there ever was one, that it is long extinct. In truth, however, I doubt that the claim of a majoritarian perspective is central, or even important, to the critical argument. Rather, the critical argument must surely be that the ability to appreciate a scholarly perspective is influenced by the reader's background, and that the backgrounds of most of those who vote in law school faculties, whatever their particular preferences in scholarship, make them less likely to appreciate the work of those whose backgrounds are very different. Without regard to the merits of this argument, it is surely a stronger one than the assertion that those who vote share a set of preferences. They surely do not; the most that could be claimed is that they share certain aversions. The important issue for those who believe this to be true is what should be done about it.

My view is that if one believes that a standard is biased and exclusionary, the solution is not to suggest that another exclusionary standard be employed alongside it, but rather to fight for a new standard that will not have the problems of the old. Can this be done in the world of legal academia? If it can't, I am prepared to stop voting on faculty appointments. As it happens, however, I think it can, and I will turn in a moment to the design of such a standard and the reasons for my confidence that what I propose would not disadvantage any serious scholarly perspective. But first I must pause to say a few words about the use, and misuse, of the idea of difference.

\section{III}

The most troubling aspect of Johnson's article, and of the entire debate over voice, is the effort to sort out whose voice of color various scholars are using. Thus, for example, I learn from Johnson that I "speak with a dialect of the voice of color that may be reflective of color but not of class affiliation with the poor and oppressed" and that I have "adopted the values of [my] majoritarian peers." ${ }^{33}$

Wow! All of this from an essay about hiring standards in law schools? It is hard to imagine that Johnson has, from a single piece of writing, figured out so thoroughly where my sympathies lie, although that move, too, is common in an era when deconstruction reigns. I think, however, that he is conflating two separate points-where one's sympathies lie and what policies one advocates.

33. Id. at 2036. 
The notion that one can work out from my essay what my "class affiliations" are is a little bit like the idea that one can decide from my position on the Gulf War whether I am a patriot or not. Labels are useful tools for rousing emotions and avoiding complexity, but I have found precious few that contribute much to discussion.

Even if we assume, with Johnson, that it is possible to work out one's "class affiliation" and "viewpoint" from an essay like mine, it isn't clear how far this advances discussion. In the essay, I criticize affirmative action-not oppose it, but criticize it. If it is Johnson's theory that criticism of (or even opposition to) affirmative action signifies a lack of solidarity with the most oppressed people of color, then he must further be assuming that affirmative action has been of some assistance to the worst off among people of color, the poor and oppressed that he describes. Unfortunately for that assumption, there is no evidence that affirmative action has helped the most disadvantaged black people, although there is considerable evidence that it has assisted the black middle class, which is, I assume, the class with which Johnson has decided that my affiliations lie..$^{34}$ On the other hand, there is considerable and largely uncontroverted evidence that many and perhaps most black people oppose affirmative action in the sense of preferential treatment, and the more the programs emphasize different standards for black and white, the lower the level of black support. ${ }^{35}$

Besides, can it really be Johnson's theory that the poor and the oppressed have a special and monolithic view on this point? What, then, does one say to the poor, oppressed person of color who is also a critic of affirmative action, who proclaims herself ready and willing to meet and beat any standard that white society places in her way and calls upon others to do the same? Is she a class traitor?

The question is not hypothetical. What I hear from the poor and working class black people that I know is an exhortation to do things that Johnson would presumably say involve an adoption of majoritarian values: To excel by beating white people at their own game. To prove that the standards that they set up are no barriers to us. Stuff like that. Well, perhaps these are not the right oppressed people, or perhaps they are brainwashed or do not have the right

34. For discussions of the evidence, see, e.g., T. SOWELL, PREFERENTIAL POLICIES: AN INTERNATIONAL PERSPECTIVE 156-59 (1990); W. WILSON, THE TRULY DISADVANTAGED, THE INNER CITY, THE UNDERCLASS, AND PUBLIC POLICY 109-24 (1987). As I explain in my forthcoming book, the fact that racial preferences operate principally to the benefit of the people of color who are already best off is not a decisive argument against it. The fact does suggest, however, that it is a program of assistance for the middle classes and should be discussed in that light, which in turn implies that support for or opposition to it bears no relation to one's sympathies with the poorest and most oppressed members of the community. See S. CARTER, REFLECTIONS OF AN AFFIRMATIVE ACTION BABY, supra note 5.

35. See, e.g., L. SIEGELMAN \& S. WELCH, BLACK AMERICANS' VIEWS OF RACIAL INEQUALITY: THE DREAM DEFERRED 126-32 (1991). For a fascinating collection of survey data presented in tabular form see id. at 129. 
perspective. Perhaps only certain people of color, maybe even a small subset, know what the authentic perspective of poor black people is.

Actually, we needn't guess at it. We have survey evidence, and lots of it. We know, for example, that black people are somewhat more likely than white people to oppose abortion. We know that black people are far more likely than white people to believe that courts are too lenient in assessing the rights of criminal suspects. And we know that black people are one of the strongest demographic groups in the country in their support for organized classroom prayer in public schools. ${ }^{36}$

My point is not that one who is interested in articulating the authentic perspective of the truly oppressed people of color must come out in favor of organized classroom prayer. ${ }^{37} \mathrm{My}$ point, rather, is that even if there is an authentic "perspective of the oppressed," I would hesitate to conclude that law professors, of all the various folks one might imagine, are in the best position to articulate it. ${ }^{38}$ If, however, law professors are going to articulate the perspective, it would be useful first to take the time to work out exactly what the perspective is. What we should not do is assume that we know what it is merely because we know what we want it to be.

The trouble with Johnson's approach, I fear, is that it glosses a bit too lightly over the matter of the use to which the proposition of difference should be put. Johnson seems to imagine that since he has, he believes, refuted Randall Kennedy's arguments (or those he attributes to Kennedy) and demonstrated that a voice of color exists, the different voice is ipso facto to be specially valued for the unique perspective that it can bring. But it is the second point, not the first, that forms the basis of Kennedy's argument: the claim that Kennedy makes is that even if a voice of color exists, no one has demonstrated that it offers a perspective that will otherwise be missed ${ }^{39}$ I must confess that I do not find any persuasive refutation of this claim so far in the extensive critical literature that Kennedy's article has generated. ${ }^{40}$ Part of the difficulty, howev$\mathrm{er}$, is epistemological: Kennedy is demanding data for a point that many take as intuitively obvious. The narrative form that critical race theorists sometimes select is meant in some sense to be an argument in itself, presenting its own challenge by its very existence: Could someone white have written this?, the stories demand.

36. There are many sources of data supporting the relative conservatism of black Americans on most social issues other than race. The particular examples in the text are drawn from data collected in NATTONAL RESEARCH COUNCIL, A COMMON DESTINY: BLACKS AND AMERICAN SOCIETY 215 (1989).

37. I do think it useful, however, to bring to the attention of white scholars information on the role of the church in the black community, something that many liberals, with their often over-zealous commitment to the trivialization of religious faith, see Carter, Treating Religion as a Hobby, supra note 2, might fail to understand or prefer to ignore.

38. Randall Kennedy offers a similar caution. See Kennedy, supra note 6, at 1788-1801.

39. Id. at 1775-78.

40. See, e.g., Responses to Randall Kennedy's Racial Critiques of Legal Academia, 103 HARV. L. REV. 1844 (1990); Delgado, Storytelling for Oppositionists, 76 VA. L. REV. 95 (1990); Johnson, supra note 9. 
The implied question is entirely rhetorical; the reader is meant to understand that the answer is $\mathrm{No}^{41}$ And if the answer is No, then the story is saying something that would not be a part of the debate were the voice in which it is written not allowed to play a part. Consequently, the debate is impoverished if the distinct voice of color is absent, which is said to be a reason to go and seek the voice.

I have no doubt that people of color, forged in the crucible of racism, will develop perspectives, politics, even aesthetics that will be at variance with those of the larger culture. As I explain in my book, I have no quarrel with the proposition that people of color and people who are white hold different perspectives, both because it is trivially true that all people hold different perspectives and because it is importantly true that the experience of oppression has touched all black people of whatever status (albeit not to the same degree). ${ }^{42}$ I do quarrel, however, with what I might call-to borrow Johnson's phraseology - the hierarchical elitist standard of suffering, to wit, "I've suffered more than you have, and therefore I know more about suffering than you do, and therefore what I have to say about suffering is more valuable than what you have to say about suffering." Judith Shklar has offered what seems to me an apt rejoinder: "Victimhood happens to us: it is not a quality."43

Even if one accepts the case for a unique voice of color, or even a range of voices, one must be cautious about advocating any policy based on the conclusion. For reasons that I explain in greater detail elsewhere, this line of argument, although perfectly understandable and sometimes even plausible, is potentially a recipe for disaster. ${ }^{44}$ If we rely on intuition rather than data in such matters, we are in a treacherous situation. After all, it is fine for one theorist to say proudly and forcefully: People of color have a unique and particularly valuable voice. As a logical matter, that is no different than the statement, evidently believed by most white Americans, that people of color have $a$ unique and generally lower intelligence than white people. ${ }^{45}$ The fact

41. Daniel Lewis James, a.k.a. Danny Santiago, thought the answer was Yes, but his critics disagreed. See Dunne, The Secret of Danny Santiago, N.Y. REv. OF Books, Aug. 16, 1984, at 17. On the other hand, Shelby Steele, whose recent book, The Content of Our Character, has come in for sharp criticism from some Critical Race Theorists, seems to me to be writing in precisely the storytelling mode that Johnson exalts. For a discussion of Steele in this context, see Carter, The Logic of Racial Preferences, TRANSITION No. 51, 1991, at 158, 178 (reviewing S. STEELE, THE CONTENT OF OUR CHARACTER (1990)).

42. See S. CARTER, REFLECTIONS OF AN AFFIRMATTVE ACTION BABX, supra note 5, ch. 9.

43. J. SHKLAR, ORDINARY VICES 17 (1984). For a detailed statement of my own views, see S. CARTER, REFLECTIONS OF AN AFFIRMATIVE ACTION BABY, supra note 5, ch. 9; Carter, Loving the Messenger, supra note 2, at 338; $c f$. P. WILLIAMS, THE ALCHEMY OF RACE AND RIGHTS: DIARY OF A LAW PROFESSOR 121 (1991) (suggesting that diversity "should not be understood as an attempt to replace an ideology controlled by 'white men' with one controlled by 'black women'-or whomever. The real issue is precisely the canonized status of any one group's control.").

44. See Carter, Loving the Messenger, supra note 2. This argument is also discussed in chapter 9 of S. CARTER, REFLECTIONS OF AN AFFIRMATIVE ACTION BABY, supra note 5.

45. The most recent General Social Survey, a regular report of the widely respected National Opinion Research Center, found that 53 percent of white respondents consider black people generally less intelligent than white people. See Poll Finds Whites Use Stereotypes, N.Y. Times, Jan. 10, 1991, at B10, col. 6. Prior 
that the second statement is racist and the first is not does not create any logical means for distinguishing one from the other. ${ }^{46}$

There is an important point here, one that those who are concerned about the possibility of racism in their white colleagues should not overlook. Even as the voice of color gains a foothold in the academy, we have to be cautious about assuming that anybody's mind has been changed. I do think that theorists who are white, whether on the right or the left, tend to celebrate the work of theorists who are not white when it agrees with their own predilections, but this is not an endorsement of the value of diverse viewpoints; it is, whether consciously it or not, nothing more than affirmative action in the old fashion. The celebration is not of the quality of the argument but of the skin color of the arguer. What many white intellectuals seem to like is an endorsement of their views on race from a person of color.

This is one of the reasons that I worry when I see white professors nodding sagely at the idea that their colleagues who are not white will bring into the law schools the points of view of the truly disadvantaged. I do not doubt the sincerity of white supporters, but I am a bit concerned about what they must envision. I worry that as they await the introduction of this new and previously excluded voice, they will actually be seeing their colleagues of color as, according to James Baldwin, white audiences saw the black actors in Carmen Jones. "[T] hese are exceptional Negroes," wrote Baldwin, "as American, that is, as you and me, interpreting lower-class Negroes of whom they, also, are very fond. ..." ${ }^{\prime 47}$ Baldwin's point, I think, was that the introduction of what might be called an interpretive class of black folk to mediate between lowerclass blacks and middle-class whites made it easier for whites to disengage from the subjects of the interpretation. One is reminded of Spiro Agnew's line, "You don't learn about poverty from people who are poor, but from experts who have studied the problem." If it is to be the task of scholars of color to articulate the perspectives of the poor and the oppressed, I suspect that the comfort level of liberal white colleagues will be increased, not decreased. And if the perspective that the interpreters articulate turns out to be something to the left of the authentic one-school prayer, fewer rights for criminal defendants, and the rest-the comfort will be greater still.

surveys through the late 1960's had shown a decline in the percentage of white respondents who consider black people less intelligent. Historical polling results on the attitudes of white Americans about black Americans are collected in NATIONAL RESEARCH COUNCL, supra note 36, at 118-24. For a more detailed discussion of data collected during the 1980's, see L. SIEGELMAN \& S. WELCH, supra note 35, at 85-100.

46. See Carter, When Victims Happen To Be Black, supra note 16, at 434 , wherein I also suggest possibilities for distinguishing among propositions of this kind, although I further explain why the simple argument that some of them are racist turns out to offer little guidance.

47. J. BALDWIN, Carmen Jones: The Dark ls Light Enough, in NOTES OF A NATIVE SON 46 (1955) (emphasis in original). 
The trouble with the argument over scholarly voice is that it is a battle over the wrong issue. The value of scholarship should not turn on the approach that a scholar takes, the perspective that a scholar articulates, or the style in which a scholar writes. The value of scholarship is a function of the purpose of the scholarship and the skill with which the purpose is carried out.

My view of how one judges the quality of scholarship rests on a simple axiom: The purpose of scholarship is to increase human knowledge. The corollary is that the greater the degree of the contribution to human knowledge, the greater the value of a particular scholarly work. Any test for scholarly quality, then, should rest on answering the question: Does this scholarship increase human knowledge, and if so, by how much?

Johnson seems to suggest that scholarship by people of color in the distinctive voice of color is inherently valuable. ${ }^{48}$ I would rather put the point differently. A more serious version of the claim would hold that scholarship by people of color about oppression with which they have had experience is more likely than work by white scholars to make a fresh and distinctive contribution to human knowledge. ${ }^{49}$ The reason it makes a difference to state the matter as a probability is that, so stated, it is at best a guideline for those planning to write; it has no message for those seeking to read. So stated, the claim is about the value of a genre. It makes no claim about the value of any particular piece of work within the genre, and each piece of scholarship must, therefore, be evaluated on its own.

An example might make the point. When I was in the eleventh grade, my English teacher, obviously no statistician, told the class that Hamlet was the greatest play in the English language. Her argument was twofold: Shakespeare, she said, was the greatest English-language playwright, and Hamlet, she added, was Shakespeare's greatest play.

The argument, of course, doesn't work. Tennessee Williams could be a lesser playwright than Shakespeare and A Streetcar Named Desire still a better play than Hamlet..$^{50}$ The distinction that my teacher was missing is between a median and a distribution. It is possible that Shakespeare's plays cluster around a higher median quality point but Williams still wrote one play well beyond his median level, and beyond Shakespeare's too.

With the voice of color literature, the same example works. Assume the truth of the arguments for the existence and value of a distinct voice of color. This might imply that Scholar White would ordinarily have less to contribute

48. See Johnson, supra note 4, at 2040-61.

49. Cf. Williams, Metro Broadcasting, Inc. v. FCC: Regrouping in Singular Times, 103 HARV. L. REV. 525 (1990) (suggesting that case for racial diversity in ownership of broadcast facilities rests on likelihood, not certainty, that people of different cultural backgrounds will make different programming choices).

50. I make no claim concerning the relative merits of the plays or the playwrights. 
to the study of law and race than Scholar Black, but that would say at best that Scholar White's work clusters around a lower median point. The distinction would provide no basis for a comparative evaluation of any particular article by Scholar White against any particular article by Scholar Black-any more than the presupposition that Scholar Quick is brighter than Scholar Slow should provide a basis for a comparative evaluation of any particular article by Scholar Quick against any particular article by Scholar Slow. You can't tell the answer until you read the work.

I labor this argument because I want to make clear why nothing about the quality of a particular piece of scholarship turns on whether one accepts or rejects the argument for a distinct and valuable voice of color; nor, if one accepts the argument, on what one imagines that the distinct and valuable voice of color is, or on one's view about whether there is a best authentic voice of color or there are multiple voices, all of them equally authentic and valuable, as Johnson proposes. ${ }^{51}$ No matter the probable value of any particular scholarly contribution, one must still finally evaluate it; and it is in the process of that evaluation, I contend, that standards can and should be universalized. ${ }^{52}$

I lack the space to set forth in detail my view on what makes some scholarship good and some scholarship bad, but it is worth mentioning what should be two very basic requirements, because both are all too often lacking in some of the writing held up to me by colleagues of all backgrounds and political persuasions as reflecting work of the sort that they believe a place like the Yale Law School ought to "include."

The first of these is that a scholar must know a field. A scholar must be familiar with the work that has gone before, the giants or midgets or simply regular folk on whose shoulders she necessarily stands. This means that serious scholars should not, for example, cite old mythologies or their own instincts as though they are facts. To take a single example, I am constantly astounded at the number of students who write papers, and the number of law professors who write articles, assuming quite casually that Southern chattel slavery destroyed the family and value structure of its black victims. Once upon a time that was virtually holy writ, but after the work of Herbert Gutman, ${ }^{53}$ Eugene Genovese, ${ }^{54}$ and others, every serious historian is aware of the mountain of evidence suggesting that despite their many other predations, slaveholders usually left family structures intact. At the very least, one would hope that a serious scholar adhering to the old idea would take the time to explain why the consensus among professional historians is wrong.

51. See Johnson, supra note 4 , at 2012-20.

52. To say that there are standards is not, of course, to say that the process is mechanistic; but the critics must be wary of stating the converse, that because the process is not mechanistic, it must not have any standards.

53. See H. GUTMAN, THE BLACK FAMILY IN SLAVERY AND FREEDOM 1750-1925, at 257-326 (1976).

54. See E. GeNOVESE, ROLL, JORDAN, ROLL: THE WORLD THE SLAVES MADE 450-58 (1974). 
Similarly, any number of law review articles make factual assumptions or assertions without giving the slightest indication that the author has even tried to find out if anyone has ever tested the proposition in question empirically. No one, I hope, would insist that anybody cite everything, and no scholar is under any obligation to agree with previous work, or even to consider it important. But when an article with scholarly pretensions ignores large bodies of relevant work entirely, the critic properly questions the intellectual seriousness with which the work was undertaken.

The second point about good scholarship is that it should not only do something that is different from what past work has done, it should also make claims that are not obvious in light of past work. A serious and innovative scholar searches for more than the way that anybody with a particular scholarly bent would address the particular problem to which she has turned her attention. The standard that work must be new is simply a matter of what the law reviews sometimes call preemption: Did the writer think of this idea first or is it already in the literature? A writer who consistently repeats what has already been written is not advancing human knowledge.

The standard that a work must not be obvious is, if anything, forgotten more often than the point that the scholar must learn the field. Again, I am more than a little discouraged when my colleagues put forth as examples of analytical brilliance work that any competent scholar applying the tools in question to the problem in question would have produced. I do not deny that some very good work may be entirely derivative in nature; but the most important, most innovative work is not, and the most innovative scholars define themselves by the originality, not just the novelty, of their conceptions. For that reason, the test is not whether the scholar's idea would have been obvious to the very best scholar in the field, but whether it would have been obvious to the ordinary scholar in the field. ${ }^{55}$

Nor is the application of this principle something outside the range of human judgment. This is precisely the test that is applied when an individual seeks a patent on an invention. If, in the judgment of the Patent Office or a reviewing court, the invention at the time it was made would have been obvious to an individual of ordinary skill in the field, a patent must be denied. The patent system, for all of its faults, has managed over time to digest the "nonobviousness" requirement rather well. There is no reason to think that law faculties, or other university faculties, should do any worse in applying it; and there is no inherent reason to suppose that it must be entirely arbitrary in its application.

As it happens, the federal law of patents includes models for both parts of my second standard. Section 101 of the Patent Act grants a patent to anyone

55. As one might expect, this test makes it harder to do good scholarship in crowded fields. In a market where candidates seriously want to be hired, this result should push people into relatively empty fields-not a bad idea. 
who "invents or discovers any new and useful process, machine, manufacture, or composition of matter, or any new and useful improvement thereof," 56 subject to other restrictions contained in the Act. For my purposes, the key restrictions are two: first, the requirement under section 102 that the invention be novel in the sense that nobody else thought of it first ${ }^{57}$ and, second, the prohibition under section 103 on a patent for an invention when "the differences between the subject matter sought to be patented and the prior art are such that the subject matter as a whole would have been obvious at the time the invention was made to a person having ordinary skill in the art to which said subject matter pertains." 58

The section 102 requirement of novelty is understood in the law schools-I have already mentioned the concept of preemption-although I often hear excuses made for various scholars' repeating what has already been said before. One of my favorites went something like this: "Well, maybe he didn't know there was another article about it, so he still thought of it himself, so you have to give him credit for having the smarts to work it out!" (It's amazing the twists that the star system will make to protect its own!) The trouble with the excuse is that a scholar who doesn't know what work has been done in the field does not deserve credit for being lazy, and as for being smart, that is not part of the test for scholarly quality; the fact that a person is smart does not mean that the person has added anything to human knowledge.

The section 103 requirement is less understood, but it is just as important. The rule is that when one sets on one side the prior art-what existed in the field at the time the invention was made-and sets on the other the invention itself, the differences between the two-the advance that the invention makes over the art-must not have been obvious at the time of invention to an inventor of ordinary skill..$^{59}$ The essential point of the section is this: The smaller the increase in human understanding as a result of an invention, the weaker the case for a patent. By analogy, it rarely increases human understanding to turn well-understood analytic tools on a familiar problem and come up with a perfectly competent treatment that any scholar of ordinary skill would have done by applying the same tools to the same problem.

This is not to suggest that no scholarship is good scholarship unless it does something that few scholars would have thought to do; rather, the point is that the more distinctive and unusual the problem solved, or the solution offered, the greater the increase in human knowledge, and, therefore, the higher the quality of the scholarship. The patent law recognizes this point through its

56. 35 U.S.C. $\S 101$ (1988).

57. 35 U.S.C. § 102 (1988).

58. 35 U.S.C. \& 103 (1988).

59. Because the test is the inventor of ordinary skill, it does not matter that the inventor in question was savvy enough to develop the invention, nor that a few of the brightest people in the field might have invented it too had they but turned their minds to the same question. See Standard Oil Co. v. American Cyanamid Co., 774 F.2d 448, 453-55 (Fed. Cir. 1985). 
award of greater protection from infringement to "pioneer patents"-patents on inventions that open up bold new avenues of exploration. ${ }^{60}$

Nor do I suggest that any scholar exceeds these guidelines all the time, or, indeed, very often; certainly I make no such claim for my own work. ${ }^{61}$ But my claim is not that every article must, in effect, deserve a patent if it is to be adjudged a good piece of work; my claim, rather, is that the works of scholarship that can meet the patent test are better-add more to human knowledge- than the works that cannot. So if one wants to argue the relative merits of different scholarly works, the patent law tests of novelty and nonobviousness provide useful and workable starting points.

Taking the patent law as a model would provide the crucial link between the purpose of scholarship -the advancement of knowledge-and evaluating the quality of scholarship. There is nothing in the test that would advantage any particular voice or perspective; on the contrary, the test that I propose would unchain the engine of creativity, for it would in effect add points for tackling unusual problems in unusual ways. It would promote and harness diversity rather than pushing people toward replicating the style or conclusions of those who have gone before.

In fact, the patent law anticipates the possibility that the evaluators might prefer inventions of one kind rather than inventions of another. Section 103, the provision requiring that inventions be nonobvious, includes another tantalizing line: "Patentability shall not be negatived by the manner in which the invention was made." 62 The sentence was intended to overturn some older cases adhering to what was known as the "flash of genius" test ${ }^{63}$-the idea that the more trial-and-error went into an invention, the less its suitability for a patent-but it is just as applicable to the idea that some scholarly modes are superior to others. The relevant question should not be, as I sometimes hear murmured, whether one line of attack on a problem is "promising" or not, for that implies the comparative judgment that section 103 forbids; rather, the relevant question should be what has resulted from the particular mode that the scholar has selected for work.

One might object, of course, that majoritarian faculties, as Johnson calls them, will not apply the patent-style test fairly, and that is always a possibility. But at least it is a test that would put all arguments on the same footing; if one wants to say that this article by Scholar Black is better than that article by

60. For a discussion of the differing breadth of protections for different inventions, see Merges \& Nelson, On the Complex Economics of Patent Scope, 90 CoLUM. L. REV 839 (1990).

61. This is, I suppose, an argument in favor of hiring relatively productive rather than relatively unproductive scholars: assuming equal skill, the productive scholar will advance human knowledge more often than the unproductive one will.

62. 35 U.S.C. $\S 103$ (1988).

63. See, e.g., Cuno Engineering Corp. v. Automatic Devices Corp., 314 U.S. 84 (1941). Cuno Corp was overruled by the 1952 Patent Act's "nonobviousness" requirement, as confirmed in Graham v. John Deere Co., 383 U.S. 1 (1966). 
Scholar White, one at least now has rules within which the battle can be fought, and the possibility of agreed rules is a considerable improvement over the current situation, in which there are as many versions of the rules for evaluation as there are evaluators.

To summarize, then, what it means to say that good scholarship must advance human knowledge: first, the scholar must demonstrate command of the relevant field, not through stringing together unnecessary citations but through making plain an appreciation of the work that has gone before; second, the argument must be new, meaning that it has not been said before; and third, the argument must be nonobvious, meaning that a scholar of ordinary skill, turning to the same problem with the same tools would not produce essentially the same argument.

Before I close, I should make one small point about the debate over what Johnson calls the existence and worth of the voice of color. As I have said already, I have no doubts that scholars of color, like all people of color, are affected by their backgrounds and, one hopes, inspired by them. I do object strongly to suggestions that some conclusions reached by scholars of color are more sensitive to the true voice of the oppressed than others. Loyalty tests are always disturbing, particularly in the academic world, where the expression of ideas should be freest.

Johnson, I hope, shares this view. As he says in closing his article, "It is our differences that strengthen us in our quest to achieve this common objective. If we lose sight of this common objective and engage in vitriolic debate concerning which viewpoint is 'correct,' we will then let our differences divide us, and our shared objective will never be realized." ${ }^{64}$ What is most important in the debate, therefore, is not whether my argument (or Johnson's or anyone else's) is accepted or rejected; it is, rather, that a debate continue. The legacy of racial oppression rests heavily on the shoulders of people of color in Ameri$\mathrm{ca}$, and the question of how best to lift it motivates all of us who enter this fray. Our problems are too large, and too complex, for us to suppose that some solutions are a priori not to be proposed. It is time to step away from labels and categories, time to stop worrying about who is writing from what perspective, time instead to join together in open and robust and healthy dialogue over the shape of the future. The future, after all, has a way of happening to us, whether we take the time to talk about it or not.

64. Johnson, supra note 4, at 2063. 
HeinOnline -- 100 Yale L.J. 2086 1990-1991 